\title{
IDENTITIES IN FORMATION NATIONALITY, RELIGION AND \\ TRANSNATIONAL IDEAS IN FORMER SOVIET CENTRAL ASIA*
}

\author{
MUSTAFA AYDIN
}

\section{Central Asia's Quest for Identity}

The political tremors experienced in international relations since 1989 significantly altered political geography of Eurasia, swecping away at the same time the international system that had becn built up over many years and certaintics that many pcople belicved to be inviolate. Within less than seven years since the World had heard Gorbachev's rise to power in Moscow, he came to supervise the disintegration of the last of the great cmpires. Instead, within the vast area once governed centrally from Moscow, suddenly emerged 15 new states, 'some of which, in modern times, have never enjoyed the status of independent actors in international politics'. ${ }^{1}$

As the newly independent statcs (NIS) started to search for orientation and were open up to outside influences, many older states volunteered to be instrumental in their quest within the emerging international system. Although the scarch for national identity and place within international

* This is a revised version of a paper delivered to $6^{\text {th }}$ ESCAS Conference on Central Asia: A Decade of Reforms, Centuries of Memories, 8-10 October 1998, Venice, Italy. It will shortly appear as 'Identities in Transition; Nationality, Religion and Regional Security in Former Soviet Central Asia' in a volume edited by G. Bellingeri for the ESCAS (European Socicty for Central Asian Studies).

${ }^{1}$ B. Z. Rumer, The Potential for Political Instability and Regional Conflicts' in A. Banuazizi and $M$. Weiner (eds.), The New Geopolitics of Central Asia and Its Borderlands, London, 1994, p. 88. 
system for the wcstern NIS were quite straight forward process, the same cannot be said for the castern NIS in former Soviet Central Asia. Their search for future orientations were complicated by economic difficulties, contested borders, mixed national groups, and more importanlly by competition of outsiders for influence that also posed serious risks to regional security. Although much had happencd since the collapse of the Soviet Union and the reluctant independence of the Central Asian states, it cannot be argued that we have secn the last phase of the cvolution in Central Asian geopolitics. The five central Asian (plus threc Transcaucasian) states may yet fragment or realign along, for cxample, national, cthnic, rcligious, or economic lines, and the outcome, 'indecd the very process, threatens to alter political and military equations from China to the Balkans'.

Morcover, the conquest and the long-rule of Central Asia by Russia had created a relationship of strong dependency between the peoples of this region and the Russian Statc/Sovict Union that changed only slightly since the collapse of the Sovict rule. Thus, all of the Central Asian Icadership, self-declared nationalist now, still make use of the old Communist Party structures, and the same elite that ruled under the former Sovict system, still ' governs. ${ }^{3}$

At some stage of the continuing process of self-identification within these states, their leaders will be replaced by new faces, and nationalism and Islam should be expected to play important roles in this process. Conversely, this will be another source of short term instability not only within these states but also in the wider Eurasian context, as the process will inevitable bring about questions regarding the future orientations, both domestic and international, of these states, which will undoubtedly attract the attention of outsiders thus creating tension and suspicion among the supporters, domestic and extcrnal alike, of each side of the argument. ${ }^{4}$

Accordingly, this paper will discuss the competition of different forces for the minds and hearths of the newly independent Central Asian states, and also the effect of international involvement in the discussion. Moreover, the possibilities of new conflicts flaring up in consequence to these discussions

\footnotetext{
2 Ibid.

${ }^{3}$ Exceptions have been Azerbaijan, where for a time the nationalists under the leadership of Abulfez Elchibey ruled briefly, only to be replaced by Haider Aliev, an old-timer and former head of Azerbaijani KGB; Tajikistan, where Kakhar Maghamov was removed from office because of his alleged support for the coup of August 1991; and Georgia, where nationalist leader Zviad Gamsakhurdia took the country into bloody ethnic war, and then replaced by Shevardnadze.

${ }^{4}$ M. Aydin, 'Turkey and Central Asia: Challenges of Change', Central Asian Survey, Vol. 15 (2), 1996, pp. 163-164.
} 
and related problems of ethnicity and identity will be evaluated with an interest to explore the existing threats to regional security and instability.

It is clcar by now that the disintegration of the Sovict Union also meant the discrediting of Communist ideology and the social and economic model based upon it. The result was an idcological vacuum in all the lands of the former Soviet Union. Conscquently, the NIS of Central Asia from the first day of their independence faced all-imposing task of the necessity to replace age-long state ideology with a new thinking that could also help them to define their separate 'identitics'. The fact that this had to be accomplished while the nation-and-statc building was going on within cach of these entities, and that the regional rivals were striving to effect the process as the outcome would also determine the forcign policy orientations of these states, did not render the process any casicr.

Morcover, although Central Asia in general 'had a long and rich history' and 'various level of identification were discernible among the Central Asian pcople', the individual states as they arise from the Communist domination had no separate identities. ${ }^{5}$ Most of them never had a sense of 'nationality' in modem sense of the concept. Before the Russian conquest of the arca, local people had mainly identified themselves with their families, clans, tribes, locality and sometimes religion. The Soviet period, though creatcd five union republics in the region, did not help the situation. The borders of the union republics, drawn originally in 1920s and redrawn again during the Stalin era, hardly coincided with any historic boundaries or with the linguistic and cultural affinitics of the different sub-populations. They divided people and shattered whatever identity and 'sense of belonging' existed hitherto and attempted to replace them with new identitics flowing from officially recognised republic borders.

However, as an end-product of this process, the nationalities in Central Asia today are at best a mixture of various local, tribal and clan groups, and 'cven a causal look at the ethnic overlap of nationalitics from one state to another' as well as artificial nature of the boundaries between them easily suggest to the observer that 'ethnic issues are a potential crisis for nearly all Central Asian states' and could destroy the political equilibrium both within, and between, them. ${ }^{6}$

In their struggle to define themselves, the former Soviet republics of Central Asia have faced, as put by Fuller, a fundamental question: 'Is a single Central Asia identity possible?' Or, if not, should they align themselves with

\footnotetext{
${ }^{5}$ G. Fuller, 'Central Asia: The Quest for Identity', Current History. Vol. 93. No. 582, 1994, p. 145.

${ }^{6}$ Ibid.
} 
other parts of the world or regional powers with whom they 'discovered' suddenly that they were sharing some sort of 'kinship', based on ethnicity, religion, language, culture, etc? If ycs, what should be the criteria that would eventually determine the outcome? While it is clcar that 'the new states require a national consensus about their place in the region', it is not at all obvious where this consensus lies: with Russia, Asia, the Muslim world, or the Turkic world. ${ }^{7}$

In this context, there were, 'broadly speaking', three distinct identity 'cards' that 'the Central Asians could play', thus the cnsued idcological discussion in Central Asia since the collapse of the Soviet Union had three dimensions: cthno-nationalism based on local ctnics such as Turkmen, Kyrgyz, Kazakh ctc; transnationalism based on Turkic or Persian nationalism or Greater Turkistan movement; and Islam, while western-style liberal democracy trailing bchind as an idcal form. Although, the political structures that have cmerged at the end of this debate have some clements of all three, it is essentially a mixture of them blended with cult personalitics of local leaders and authoritarian rulc. ${ }^{8}$

\section{Ethnonationalism, Transnationalism and Central Asian Federation}

The scarch for unity among the Turkic peoples of Central Asia is not new and even predates the Russian conquest of the region. However, they were never adequately unified on common grounds to form a united front against Russian inroads towards the region. Yct, there was sufficient unity among the Turkic peoples of the region when they actively opposed to the decision of central Communist Party organs of the Sovict Union' in 1924' to divide the Central Asia into national territorics: 9

7 Ibid.

${ }^{8}$ M. B. Olcott, Nation Building and Ethnicity in the Forcign Policies of the New Central Asian States' in R. Szporluk (ed.), National Identity and Ethnicity in Russia and the New States of Eurasia, New York, 1994, pp. 216-220, identifies the 'ethnic cards' that these states could use in their international affiliations as their Turkic or Persian nationality, their Islamic religion, and their 'Asianness'. On the other hand, S. T. Hunter, Central Asia Since Independence, Washington Papers, No. 168, London, 1996, mentions three 'major trends' as ethnonationalism and transnationalism, Islam, and Western-style liberal democracy. For discussion, see pp. 24-39.

${ }^{9}$ The idea that Central Asia should be divided into separate nations was first introduced by Lenin when he proposed dividing Turkestan into 'Uzbekiya', 'Kirghiziya' and 'Turkmeniya'. The division itself began in 1924, and was completed only in 1936, which led to the creation of five union republics and two autonomous regions. See I. P. Lipovsky, 'Central Asia: In Search of 
However, the central authoritics went along with their plan as they feared that pan-Turkism (and/or pan-Islamism) could have challenged the supreme position of Marxist-Leninist idcology in the region. Indecd, just as they had planned, 'the division of Central Asia into five distinct republics considerably accelcrated the formation of separate nations', shaping the indescribable, 'mainly Turkic mass of the Muslim population into distinct and separatc peoples each possessing its own national consciousness, language, culture, and economic independence'. 10 During the pre-Soviet times, the region was shared among different tribes and clans, yet there were no borders, so to speak; at lcast they were not recognised by the local people who traversed them frecly without further consideration. But, it is divided now by the nation-state borders that are, by all means, recent creations. Notwithstanding how recent they are, they have been nevertheless entrenched into the minds of local pcople, who became accustomed through the years to define themselves with 'their' borders. Therefore, 'pan-Turkism in the sense of unifying all the Turkic-speaking peoples into one state is not yet, and is unlikely to become, a realistic option'.1 1 The changes 'that took place in Central Asia during the...Soviet rule largely destroyed' whatever 'pan-Turkic consciousness' may have existed in the region. ${ }^{12}$

Just as unrealistic is the intellectually attractive therefore much-toyed idea of creating a Greatcr Turkistan, which has not so far taken decp root among the ordinary pcoples of the region. In addition to disparitics in size, population, and resources of various republics, their weariness about Uzbekistan's inclination to dominate the region appears as the most important obstacle hampcring efforts in this direction. 'The idca of creating some kind of loose Turkic grouping', on the other hand, 'is very much alive and quite realistic. The regular Turkic summits could be beginning of such a grouping'. Thus the idea of a Turkic commonwealth, along the lines of the British Commonwealth, might still be possible in future. ${ }^{13}$ On the other hand, we should not forget the overwhelming difficulties in realising even this modest scheme.

First of all, Turkey's carlicr activities in the region to forge closer relations brought into minds of its rivals the question of whether Turkey is aiming for regional hegemony and/or revival of old pan-Ottomanist and pan-

a New Political Identity, Middle East Journal, Vol. 50 (2), 1996, p. 217.

10 Ibid., p. 218.

11 Hunter, Central Asia since Independence, p. 30.

12 Lipovsky, Central Asia, p. 219.

${ }^{13}$ Same view is also expressed by ibid.; Quotation is from Hunter, Central Asia since Independence, p. 30. 
Turkist unions. ${ }^{14}$ The Grecks, the Arabs and the Iranians have accused Turkey of revising pan-Turkism. Russia, too, charged Turkcy with applying 'racial critcria' in its increased activitics across the Central Asia. ${ }^{15}$ These were fuclled by Turkey's carlicr tendency to refer to all Turkic-speakers simply as Turks, and by the loosc talk about cmergence of a belt of Turkishspeaking communities from Adriatic to China. Morcover, without paying much attention to the fact that underscoring of pan-Turkism may also trigger the feelings of pan-Slavism, and pan-Persianism, Turkcy's common ethnic, linguistic and cultural unity with the Turkic-spcaking people of the Central Asia and Caucasus were extensivcly emphasised by both Turkey and the West as a part of their promotion of the 'Turkish model' in the region. 16

Apart from attracting reactive responses from its regional rivals, Turkey's excessive emphasis on commonalties between the people of Turkey and the Turkic-speaking pcople of the former Sovict Central Asia and Caucasus, also resulted in resentment among those people, since these views were in direct conflict with 'the individual and separate self-identity and national awareness formulated by each of these people'. ${ }^{17}$ It became clear within couple of years of their independence that most of the peoples in Central Asia and Caucasus, despitc their common Turkic origin, had a strong sense of distinctiveness and, at least initially, preferred to assert their own individual identity rather than be submerged within a broader cultural and political umbrclla. ${ }^{18}$

Besides, there is also the 'Russian factor' to take into account. Russia reacted to even Turkic summits, harmless gatherings for all intent, with

${ }^{14}$ For analyses of such views see, for example, O. Sander, Turkey and the Turkic World, Central Asian Survey, Vol. 13 (1), 1994, pp. 41-42; and S. S. Gürcl, "Turkish Forcign Policy in a Changing World' in Turkey in a Changing World, Tokyo, 1993, pp. 22-23. For a discussion of Ankara's steps to calm the fears of its neighbours see G. M. Winrow. 'A Stabilising Influence in a Fragile Commonwealth?: Turkey and the Former USSR', paper delivered at the $33^{\text {rd }}$ Annual Convention of the International Studies $\Lambda$ ssociation, Atlanta, GA, 31 March-4 April 1992.

15 'Turkey Extends A Hclping Hand', World Press Review, July 1992, pp. $12-12$.

${ }^{16}$ This point is further elaborated by Y. Kimura, 'Central Asia and the Caucasus; Nationalism and Islamic Trends' in Turkey in a Changing World, p. 194; and M. E. Ahrari, The Dynamics of the New Great Game in Muslim Central Asia', Central Asian Survey, Vol. 13 (4), 1994, pp. 534-536.

${ }^{17} \mathrm{O}$. Kesic, 'American-Turkish Relations at a Crossroads', Mediterranean Quarterly, Vol. 6 (1), 1995, p. 101.

${ }^{18}$ Kimura, Central Asla and Caucasus, p. 194. 
alarm and anxicty. Since Russia is still the only great power in the region, Turkey cannot afford to alicnatc or alarm Moscow by exerting too much activity in Central Asia as the Russians arc acutely sensitive to any panTurkic, as well as Islamic, trends in the region. Whilc Russia initially welcomed, for the first time, Turkish influence in Central Asia as a counterweight against Iranian dominated radical Islam, those vicws by now have shifted as Turkey moved more actively to supplant Russian influcnce in the region then Iran.

Thus Russia, getting increasingly edgy about Turkish intentions in the region, became itself, in turn, more aggressive in its assertion of its 'rights in its near abroad'. 19 Onc of the main concerns of Russia's present policies towards Central Asia appears to be dominated by its fears that the region might become a centre for Islamic fundamentalism or pan-Turkist aggression that may threaten the sccurity of Russian Diaspora in the region as well as creating unrest among Russia's own cthnic Turkic or Muslim minorities in Northern Caucasus. ${ }^{20}$ Hence, after a brief period of selfisolation, Russia cagerly moved to re-establish its place within the Central Asia and Caucasus as a dominant actor.

These developments have fuclled a Russian-Turkish rivalry that created certain dilemmas for the Central Asian countrics. The emergence of a Turkic community could help reduce their dependence on Russia and enhance their international weight. But it could antagonise Russia, Iran and China which sce pan-Turkism as a threat to their security and territorial integrity. Furthermore, Tajikistan, which is Farsi-spcaking, may be pushed politically toward Iran and Afghanistan to counter-balance the Turkic influence.

Morcover, 'in the projected commonwealth, the leading role' would have to be played by Turkey as 'the strongest and most influential Turkic country. That, however, would inevitably harm Turkey's relations' not only with its local rivals such as Russia and Iran, but may also cast further shadows over Turkey's European credentials thus endangering its future EU

${ }^{19}$ For exploration of Russia's newly asserted interests in its near abroad see $S$. Blank, 'Russia, The Gulf and Central Asia in New Middle East', Central Asian Survey, Vol. 13 (2), 1994; Also see 'Central Asia: Rumblings From the North', The Middle East. No. 230, January 1994, pp. 14-15.

${ }^{20}$ G. Fuller, Turkey's Eastern Orientation' in G. E. Fuller and I. O. Lesser, Turkey's New Geopolitics, New York, 1993, p. 76, further elaborates this point by pointing out that Russia...sees the extension of fundamentalism into Central Asia as detrimental to its own position in the region...But, in Russian cyes, aggressive pan-Turkist policies are not much better than Islamic inroads if the net effect is to dislodge Russian influence on ethnic if not religious grounds'. For Russian complaints on the issue of 'Turkic-Unity', sec FBIS-SOV, 20 January 1995, p. 59. 
membership. Morcover, as this kind of a role may 'place an cnormous financial burden on Turkish budget, ...given its present economic conditions, Turkey' would 'unlikcly' to be prepared 'to pay such a high price for leadership' in the region. Thus 'the most likely' outcome 'for a Central Asian commonwealth would be...a partnership between all the Central Asian republics... based on bilateral and/or multilateral economic and political agreements' rather than a Turkish-led attempt to create an influence-zone. ${ }^{21}$

Just as ideas based on 'Turkicness' grown after the disintegration of the Soviet Union, the Persian-speaking 'Tajiks, who felt isolated and surrounded by Turkic-speaking peoples, began to emphasise their Iranian herilage', as well. However, 'transnationalist ideas of either Turkic or Iranian varicty have, so far, not made any significant headway in Central Asia', and although the future prospects for the success of such transnational ideas and projects are difficult to assess, the experiences of other peoples (the Arabs for example) can clearly show pitfalls involved. 22

While these transnationalist idcals were gradually dropped from the agendas of Central Asians, 'ethnocentric nationalism, a much narrower sense of identity such as Uzbekness and Kyrgyzness as opposed to notions of Turkicness', Persianness 'or Muslimness, have become strong forces in Central Asia' ${ }^{23}$ This trend is further strengthened by the post-independence Central Asian leaders, who widely employ nationalist ideas to reinforce their own legitimacy. At the end of this process, however, an alternative leadership will emerge in Central Asia that will be much more nationalist than the present leadership. If we wish to get some idea of what would be the implications of a real nationalist lcadership might be, we have only to look at the insights provided by those few truly nationalist leaders and movements that emerged bricfly in the region before they were crushed (c.g., Gamsakhurdia in Georgia, Elchibey in Azcrbaijan, and the various banned nationalist parties in Caucasus and Central Asia; Erk, Birlik, Dashnak, ctc.). This suggests a future that will have more ethnic conflict rather than less, which will probably encourage the departure of minorities in a wider scale, or even possible scizure of lands where ethnic minorities exist across the border from their home state such as Russians in Kazakhstan and Kyrgyzstan.

\section{Islam}

During the first year of independence, because of Central Asia's Islamic heritage, many outside observers have suggested that Islam, in addition to or sometimes in competition with nationalism, would be one of

\footnotetext{
21 Lipovsky, Central Asia, p. 219.

22 Hunter, Central Asia since Independence, pp. 32-33.

23 Ibid., p. 34 .
} 
the defining characteristics of Central Asia in the forthcoming ycars. Giving credit to this observation, at the time, was the fact that both the long periods of Russian imperial rule and atheistic Soviet-cra indoctrination had failed to eliminate the influence of Islam from Central Asia. ${ }^{24}$ It was clear that Islam's position as an important clement of individual and collective selfidentity guarantecd its survival. Morcover, early reports from the region, where mainly in Fergana Valley Islamic opposition took upper hand bricfly, tended to confirm this argument.

However, reality was more complex, complicating the programme of nation-building throughout the region, as the independence presented the largely secular clites of Central Asia and the current Central Asian leadership with a dilemma. On the one hand, they soon realised that Islam offered various advantages' to them, who now had to struggle for 'popular support for their positions rather than being favoured by Moscow' 25 For the Sovicteducated lcaders, 'an appcal to Islamic symbols and traditions' was secn as a useful political tool in their effort to reinforce their legitimacy. As they soon found out, for the populations who, apart from 'bcing historically Muslim, had little clse to define themselves by, Islam and the values it espouses were attractive'.26 Furthermore, as mentioned carlicr, the Islamic herilage of Central Asian nations was considered as one of the trump cards that they could play in their international relations 'in order to receive massive amounts of credits, grants, and aid'. 27

Consequently, all the leaders of the region have 'sought to introduce an Islamic dimension' into their forcign policies by courting such countrics as Iran or even Libya. However, they, at the same time, 'feared too great [an inclination] toward Islam in their respective states', 28 which could have ousted them at any time and further aggravated the already complicated nation-and-state building process. Morcover, the growth of Islam's role in public life would have casily alicnated the substantial Russian minoritics, especially in Kazakhstan and Kyrgyzstan, whose skills were necded in the short term. Thus, they had no intention of allowing Islamic activism to challenge their own positions' ${ }^{29}$ Accordingly, all the post-independence

${ }^{24}$ For more detailed analysis of the subject see $S$. T. Hunter, The Transcaucasus in Transition: Nationbullding and Conflict, Washington, DC, 1994; and Lipovsky, Central Asia, pp. 211-223.

25 M. B. Olcot, 'Central Asia's Islamic Awakening', Current History, Vol. 93. No. 582, 1994, p. 151.

${ }^{26}$ Ibid., p. 152; and J. Anderson, The International Politics of Central Asia, Manchester, 1997, p. 138.

${ }^{27}$ Olcott, Central Asia's Islamic Awakening, p. 152.

28 Ibid.

${ }^{29}$ Anderson, International Politics of Central Asia, p. 155. 
constitutions of the Muslim republics emphasiscd thcir secular nature, as well as the principle of separation of religion and state.

In an attempt to combinc these conflicting positions, all the Central Asian lcaders, after gaining independence, introduced a policy of co-habitation with moderate type of Islam while preventing all political manifestations of radical Islam. The rationale bchind this co-habitation is that 'since there is a demand, it is better that this demand is met by moderatc' and sccular institutions. Otherwise, it could be met by more hard-liners, supported notably by Iran. Therefore, 'thcy have becn trying to co-opt Islam and use it to legitimate their own power while preventing its emergence as a political force' 30

However, the strategy pursued by the Central Asian countries towards Islam, namcly simultancous repression and co-habitation, by no means protects the existing regimes from the challenges of Islam, cspecially if secular political institutions are also not allowed to develop. As we have seen both in Turkey and various Arab countrics during the 1980s, the policy of co-habitation, by 'allowing more scope to religious institutions', heightening the people's Islamic consciousness and 'leading to cultural Islamisation', may provide 'rcligious leaders greater authority among the population' thus creating ' a more favourable ground for Islam to emerge as a political force' should cconomic, political and social conditions within the country take a downturn. 31

Although, excepting the Tajiks and maybc U\%bcks, Islam at present does not play an important political role in most of Central Asia, it 'remains a potent force...albeit underground. Therefore it is conccivable that in the future it may yct come to play an important social and political role'. Especially, if the development of secular democratic institutions and channels of popular expression are blocked while current governments fail to improve their people's living conditions, then 'Islam may emerge as the only vehicle for the expression of grievance and dissent'. 32

${ }^{30}$ S. T. Hunter, Islam in Post-Independence Central Asia: International and External Dimensions', Journal of Istamic Studies, Vol. 7 (2), 1996, pp. 300-301.

${ }^{31}$ Hunter, Central $\Lambda$ sia since Independence, p. 37; and Anderson, International Politics of Central Asla, p. 155.

${ }^{32}$ Hunter, Islam in Post-Independence Central Asia, pp. 209 and 303. Political Islam flourishes under certain conditions: political repression, economic hardship, social grievance, state suppression of Islamist political activity, and repression of all alternative political movements that might also express economic, political and cultural grievances, thereby giving Islamists a de facto monopoly on opposition 
The idca of a single Islamic state in Central Asia, on the other hand, is unacceptable not only to the current leadership of those republics, but also to Russia and Turkcy, whose combined influcnce is considerable in the region. Morcover, 'the presence of a large Russian' Diaspora throughout the region 'makes any attempt to cstablish an Islamic state' in Central Asia 'even more difficult' effort with dangerous intcrnational ramifications. ${ }^{33}$ Thus, 'a union of all the Central Asian countries within a single Islamic state is utopian, and the prospect for an Islamic republic along the lines of Iran in one of the Central Asian republics is weak'. Only in Tajikistan 'are the Islamists strong enough to make a claim for power. The [greater] danger for Tajikistan, howcver, is the possibility of a repcal not of the Iranian, but of the Afghan experience; a bloody civil war between rival political clans'. ${ }^{34}$

\section{Foreign Policy Dilemmas}

Central Asian nations' search for identities after the Soviet withdrawal have also been complicated by the need to develop a favourable international standing and a web of external contact for their nation-states through a viable and coherent foreign policics. Although it is now clcar that the forcign policy orientations of the Central Asian states in the final analysis will not be determined by the ethnic, linguistic, or religious factors, but rather by the economic uscfulness and political wcight of their 'friends', it has not been, by any means, casy ride for them both to reach this conclusion and to convince their 'friends' about it. ${ }^{35}$

'When the Sovict state disintegrated and newly independent predominantly Muslim states cmerged' from the rubble 'in Central Asia, a simple model for understanding their role in international politics was widely put forward. ${ }^{36}$ According to this model, the Central Asian Muslims;

will be drawn [towards their long-suppressed] Islamic identity,... which might take a militant anti-Western form and thercby increase the

and the sole voice of cultural-religious legitimacy. Sce Fuller, Central Asia, p. 147.

${ }^{33}$ Lipovsky, Central Asia, pp. 217-218.

${ }^{34}$ Ibid., p. 218.

35 Ibid., pp. $220-223$.

36 The three 'models' that summarised here were formulated by Banuazizi/Weiner, Geopolitics of Central Asia, pp. 11-14. The validity of the first model is criticised by many; among them Hunter argues that posing 'the question of what would be the dominant ideology' in the Muslim Central Asia as the choice between the so-called Iranian and Turkish models' is rather simplistic. See Hunter, Islam in PostIndependence Central Asla, pp. 298-303. 
regional power of Iran and the world-wide infuence of fundamentalism. This 'clash of civilisations' between fundamentalist Islam and the West [would then] attract other Muslims who, although not drawn to fundamentalism, [were] antagonistic to the West. In this struggle, both the West and Russia, for different reasons, [werel handicapped, but Turkey as a state [governed]...by secular-minded Muslims [was] in a position to excreise influence upon the new states because of its linguistic and cultural affinities for the majority of the Central Asians. ${ }^{37}$

Accordingly, Turkey and Iran would competc for influence in Central Asia. This was an altered version of the nincicenth-century 'Greal Game', with Turkey and Iran replacing Russia and Great Britain.

In this context, the US and initially Russia expressed their preferences for the Central Asian states to develop along Turkish model, and all the Central Asian leaders made it clear that they regarded the Turkish model as the only onc worthy of cmulation for their statcs. However, this model 'was soon recognised as overly simplistic, in part because it failed to recognise the differences betwecn Islam in Central Asia and clsewhere in the Middle East, as well as the many significant differences among these republics with respect to' their strong desire to have scparate identitics. Furthermore, 'in spite of their initial cnthusiasm in approaching these republics, it has become increasingly apparent that both Turkey an Iran lacked' the necessary 'economic resources that would have cnabled them to excreise a dominating influence in the region'. ${ }^{38}$ Morcover, Moscow, which had no coherent policy towards its former colonics on its southern borders for about a year or so after the dissolution of the USSR, suddenly from late 1992 onwards, started to exhibit a kecn interest in the region, redefining it as its 'ncar abroad'. From then on, it has become clear that the geopolitical vacuum, created by the collapse of the USSR, had proved to be a temporary phenomenon. ${ }^{39}$ Recognition of this fact ended both the speculations of Turkish-Iranian competition for influence, and the secnarios of a reformed 'Great Game'.

Apart from Russian return and diverse preference of local statcs, both Iran and Turkcy, because of various reasons peculiar to their geography and internal politics, were at a disadvantage to establish a dominating position in the region. Among the impedements that have prevented expansion of Iran's influence in the region have been its 'overwhelmingly Shi'ite' population, 'while the majority of Central Asians are Sunnis'; its openly theocratic

${ }^{37}$ Banuazizi/Weincr, Geopolitics of Central $\Lambda$ sia, pp. 11.

$38_{\text {I bid., p. } 12 .}$

${ }^{39}$ N. Diuk and A. Karatnycky, New Nations Rising; The Fall of the Soviets and the Challenge of Independence, New York, 1993, p. 132. 
character, 'which is unacceptable to Central Asian Icaders'; and its 'policy of confrontation with the West, to whom Central Asian states continue to appeal for aid and assistance'. Turkey, on the other hand, had an initial advantage over Iran because of its linguistic, historical and cultural kinship with Turkic Central Asia, and the attractiveness of the Turkish model of cconomic development and sccularisation'. However, Turkey's distance from Central Asia, its lack of common borders, and its cconomic and political problems including the Kurdish issuc, have been Turkey's disadvantages. ${ }^{40}$

As this old...model /had] given way, a new model has emerged, one that [pointed] to the role of Russia...in helping to stabilise the region. Developing, in part at least, as a response to the bloody ethnic conflicts in former Yugosavia and political turmoil in Somalia, Sudan and elsewhere in Africa, this second model stipulated that the political order among the weak states in the [new world order] depends upon the willingness and the capacity of regional superpowers to intervene...According to this view, it [was] best to permit and indeed encourage Russia to play an active role in mediating disputes within and between the Central Asian republics, even [if] it involves the excrcise of military power. 41

However, this model had two major weakncsses. First, it failed 'to recognise that nationalist Russians and sections of the Russian military have an interest in promoting conflicts in the region preciscly in order to extend their influences, as they apparently did' in various conflicts throughout Caucasus. Secondly, it also ignored the possibility that the recstablishment of Russian hegemony in Central Asia is likely to strengthen the nondemocratic tendencies that already exist both within Russia' and Central Asia. ${ }^{42}$

Although this sccond model is still in the try as Russia still struggles to dominate the region once again, another model has quictly developed in time. This model, largely adopted to by the regional states, 'emphasises their independent character and secks to strengthen this independence through membership in a varicty of bilatcral relations and regional groupings, including the Economic Cooperation Organisation'. Though it is difficult yet to formulate the outlines of such model, it is in this model, rather than the other two, that lics the real chances of long-term peace and stability in the

${ }^{40}$ Liporsky, Central Asia, p. 221.

${ }^{41} \mathrm{~B}$ anuazizi/Weiner, Geopolitics of Central Asia, pp. 12-13.

42Ibid., p. 13. Moscow is of course likely to prefer authoritarian leadership in the new Central Asian states precisely because it does offer a chance to 'keep the lid on' and avoid turmoil, at least in the short run. Authoritarian leaders in Central Asia are also likely to strike a deal with Moscow in order to strengthen their own positions. 
region. But, again the reality is more complex, and 'the protection of minorities, including Russian scttlers', cspecially remains 'critical to their efforts to create stable political systems and to avoid extcrnal intervention'. 43

\section{Conclusion}

As mentioned carlicr, 'the present neo-Communist leadership in all the Central Asian states represents only a transitional phase in the political development of these states'. Thus, in a sense, 'much of the current leadership in Central Asia does not represent the nationalist future that will ultimately emerge in nearly cvery state with the passage of timc'. The new leaders would be 'more suspicious of Russian intentions, wish to preserve their independence from excessive Russian influence and strengthen ties with the world beyond the CIS', and will be 'intent on building a modern nationalist statc on the basis of cach statc's dominant nationality and culturc'. As they gain in strength, however, 'they will change the present internal, and especially external, orientation of the former Soviet republics in new directions... In a sense, then, we have not yet seen the true face of Central Asia, which will only emerge after nationalist clements come to the fore'. 44

Up to now, we have witnessed a struggle to define their identity and to charter a forcign policy that would guarantec their continued independence. In this effort, various forces of national and transnational creed have been competing for power as well as number of regional countrics attempting to gain upper hand in influencing the outcome. However, 'the political idcology that has replaced Communism in Central Asia can best be described as secular authoritarianism with a dosc of frec market philosophy. Central Asian lcaders have concluded that, given present conditions in their countries, a period of authoritarian rulc is a neccssary stagc in transition from Communist totalitarianism to liberal democracy'. ${ }^{45}$ While the struggle for national identification goes on within cach republic, the authoritarianism provides a tcmpting solution as 'the only way to kecp the country together'. That, of course, was the justification for the Soviet iron hand. It is dismaying to see the harsh authoritarian approaches of most of the Central Asian leaders are presented as the sole response to potential ethnic divisions within their republics, and rationalisation for their own hold on power.

In the first glance, the interstate and intercthnic conflicts that rage in several of the post-Sovict republics may scem remote from the immediate interests of world at large, but unless order and peace are brought to Central Asia and Caucasus, the region could provide one of the most dangerous and

43 Ibid.

${ }^{44}$ Fuller, Central Asia, pp. 146-147.

45 Hunter, Central Asia since Independence, pp. 38-39. 
widening instability for regional as well as global sccurity. 46 If, for example, events in Alghanistan and/or Tajikistan werc to spin out of control, they would casily destabilise the entire region, draw in such nearby states as Iran, Pakistan, Kyrgyzstan, Uzbckistan, Turkmenistan; and cven such diverse states as Kazakhstan, Russia, Turkey, India and China might be drawn in for various rcasons.

On the other hand, if properly directed by lcaders of modcrate, predemocratic orientation, patriotic nationalism can contribute to the shaping of a libcral, tolerant order in much of what had been a repressive, militaristic region. Accordingly, the aid programs from the West should aim towards this direction and, by targeting the promotion and strengthening of civil society, should help to extend democracy-building initiatives within those post-Soviet states where democratic groups are challenging the old Communist nomenclature. In this context, material and technical aid should thus be extended only to those states that respect democratic norms, not to such states that suppress democratic opposition. ${ }^{47} \mathrm{Yct}$, up to now, no such step has been taken by cither regional powers or the Western states.

Although Western attention so far has becn, somewhat inevitably, focused on resource-rich and/or industrially developed countrics such as Russia and Ukrainc, a more active role should also be pursued in Central Asia, where the attempts by Russia to return as 'big brother' and its soldiers as 'peace-kecpers' added new dimensions to alrcady existing political problems and security concems.

To be sure, the new nation-states require a period of stability in interstatc relations if they are to consolidate a democratic and economic transformation. Whilc the break-up of the USSR 'has creatcd a complex and at times dangerous landscape', the fall of the Soviets has also led to a 'new environment that is less dangerous and more open to democratic possibilities than the monolithic -if predictable- totalitarian rulc' ${ }^{48}$ Therefore, there is still a strong possibility of peaceful sclf-development and nation-building process in Central Asia, which requires a delicate support of Western powers. Otherwise, the possibility of wide-scale explosion of violence should be considered only too ral.

\footnotetext{
${ }^{46}$ Diuk/Karatnycky, New Nations Rising, pp. 272-273.

47 Ibid., p. 275.

48 Ibid., p. 274.
} 